\title{
Planning at the neighbourhood scale: localism, dialogic politics and the modulation of community action
}

Article

Accepted Version

Parker, G. and Street, E. (2015) Planning at the neighbourhood scale: localism, dialogic politics and the modulation of community action. Environment and Planning C: Government and Policy, 33 (4). pp. 794-810. ISSN 1472-3425 doi: https://doi.org/10.1068/c1363 Available at https://centaur.reading.ac.uk/35147/

It is advisable to refer to the publisher's version if you intend to cite from the work. See Guidance on citing.

To link to this article DOI: http://dx.doi.org/10.1068/c1363

Publisher: Pion Ltd

All outputs in CentAUR are protected by Intellectual Property Rights law, including copyright law. Copyright and IPR is retained by the creators or other copyright holders. Terms and conditions for use of this material are defined in the End User Agreement.

www.reading.ac.uk/centaur 
Central Archive at the University of Reading

Reading's research outputs online 


\title{
Planning at the neighbourhood scale: localism, dialogic politics and the modulation of community action
}

\author{
Gavin Parker \& Emma Street, \\ School of Real Estate and Planning, University of Reading, RG6 6UD, UK \\ Email: g.parker@reading.ac.uk / e.j.street@reading.ac.uk
}

\begin{abstract}
This paper builds upon literature examining the foreclosing of community interventions to show how a resident-led anti-road-noise campaign in South-Eastern England has been framed, managed and modulated by authorities. We situate the case within wider debates considering dialogical politics. For advocates, this offers the potential for empowerment through non-traditional forums (Beck, 1994; Giddens, 1994). Others view such trends, most recently expressed as part of the localism agenda, with suspicion (Haughton et al, 2013; Mouffe, 2005). The paper brings together these literatures to analyse the points at which modulation occurs in the community planning process. We describe the types of counter-tactics residents deployed to deflect the modulation of their demands, and the events that led to the outcome. We find that community planning offers a space - albeit one that is tightly circumscribed - within which (select) groups can effect change. The paper argues that the detail of neighbourhood-scale actions warrant further attention, especially as governmental enthusiasm for dialogical modes of politics shows no sign of abating.
\end{abstract}

Keywords: Planning, Localism, Dialogical politics, Framing, Modulation, Translation. 


\section{Introduction}

This paper takes as its cues the changes to the planning system currently being actioned in England, particularly the (re)emergence of formalized modes of neighbourhood planning, and the evolving academic critique of contemporary democratic governance systems. The main focus of analysis is the way in which purportedly localist initiatives being rolled out across England chime with recent discussions around the post-political and the linked critique of dialogical styles of politics (see Haughton et al, 2013; Mouffe, 2005; Swyngedouw, 2010). We bring these critiques into conversation with long-standing criticisms of state-led efforts to empower in the planning literature (cf. Haus et al 2006; Innes and Booher, 2004; Wilson, 2005; Brownill, 2009), and actor-network analyses, where framing and translation strategies and processes are seen to shape possibilities and outcomes (e.g. Callon, 1998; 1986; Tait, 2002).

The paper contributes to existing debates over neighbourhood-scale planning initiatives by assessing the details of a case where a community challenged a government agency's practices around road maintenance. The discussion centres on the design, operation and outcomes associated with a campaign that emerged in a context in which dialogic modalities of governance dominate. A second contribution relates to a critique of writings on the post-political condition within which we situate the case study discussion. We use the detail generated by the case study to highlight what (following May, 2008) may be called the 'hope of (local) politics'. We define this as the potential opportunities for localised action that can be wrought within existing (and emerging) dialogical political frameworks. We contend that a focus on these matters of process is essential if we are to uphold the possibilities (being mindful of the limits and constraints) for community actors to exercise influence over planning and policy decisions through localist governance frameworks. 
There are concerns that the carving out of localist spaces for intervention represent little more than the reorientation or consolidation of neoliberalism towards the local scale (Brenner and Theodore, 2002; Parker, 2012; Raco et al, 2006). Moreover, for those who focus on the implications of these changes for democratic politics, the reformulation of systems of governance can be read as part of a wider attempt to confront and then "forestall the articulation of divergent, conflicting and alternative trajectories of future socioenvironmental possibilities" (Swyngedouw, 2010: 195).

In such latter accounts, efforts to reorganize systems of governance, ostensibly along pluralistic lines, have been viewed as manipulative and managerialist interventions that maintain attention on specifics and details, rather than addressing more fundamental socioeconomic questions which are likely to entail challenges to the existing socio-political order (Haughton et al, 2013). In relation to the current reforms to the planning system, observations about the 'opening up' and/or 'closing down' of channels of influence are pertinent (Stirling, 2008), and there are parallels with accounts situated within the Actor Network Theory (ANT) literature too; of attempts by actors to frame issues to suit and proceed to translate particular versions of possibility (cf. Callon, 1986; 1998, Callon et al, 2009; Parker and Wragg, 1999; Tait, 2002).

The National Planning Policy Framework (NPPF) for England (DCLG, 2012) and the Localism Act (DCLG, 2011a) establish Neighbourhood Planning (NP) and associated community 'rights'. They are purported to provide a "powerful set of tools for local people to ensure that they get the right types of development for their community" (DCLG, 2012: 44). While neighbourhood plans are offered-up as potential routes towards empowerment, there are considerable qualifications or obstacles to these possibilities. For example, plans must be in 'general conformity' with the NPPF and the strategic policies of the Local Plan as prepared by the local planning authority (DCLG, 2012: 44). In relation to development and 
growth, the scope for action is also established: "[n]eighbourhood plans and orders should not promote less development than set out in the Local Plan or undermine its strategic policies" (DCLG, 2012: 44).

This instrumental framing of the community role in local politics and planning, where predetermined parameters are set by 'absent others' (i.e. civil servants, national-level politicians, the development industry), is a recurrent theme in the literature on public participation (see Connelly, 2006; Innes and Booher, 2004). The concept of communicative planning has formed a focus for these discussions, centring on a debate over the constitution of an "open and participative enterprise...guided by a consensus-building process" (Sager, 2009a: 67). Moreover, for advocates, communicative planning can help to "promote the deliberative aspect of and create and protect the conditions for deep and genuine civic discourse" (Sager, 2009b: 3).

For others, the idea that dialogue will develop a relation of mutual tolerance highlights a degree of naivety towards the realities of power struggles and the democratic deficits that often characterise policy regimes (see Metzger, 2011; Allmendinger and Haughton, 2010). For Mouffe (2005: 11) the idea of a mutually beneficial consensus is untenable since "every consensus is based on acts of exclusion". Similar concerns have been raised in the planning theory literature (cf. Allmendinger and Tewdwr-Jones, 1998; 2001) about the veracity or likelihood of consensual outcomes being sustained or having a meaningful impact in redirecting outcomes. In addition to questioning whether collaborative frameworks can provide opportunities for citizens to challenge and/or reframe debates, we are sceptical of the extent to which deploying contested concepts such as 'community' and 
'neighbourhood' in policy strategies can help to revitalize democratic politics ${ }^{1}$. The localism agenda formed part of New Labour's wider political devolution project, and has now been enthusiastically pursued by the UK Coalition government who have called for a redistribution of power "from elites in Whitehall to the man and woman on the street" (Cameron, 2010: no page). Claims of empowerment can be linked the idea of a dialogic style of politics. Here concepts such as 'community' act as generative devices in the formation of a dialogical democracy, wherein individuals are empowered with the "psychological and material autonomy needed to enter into effective communication with others" (Giddens, 1994: 119).

The embrace of dialogic modes of politics is, in planning theory terms, presented as a necessary response to the failings of rationalistic planning (see Sager, 2009a; Conservative Party, 2010). Engendering a more engaged and discursive form of politics in application to planning questions entails the recognition and support of what Beck (1994: 22) terms sub-politics, wherein "[a]gents outside the political or corporatist system are allowed to appear on the stage of social design". These include citizens, technical experts, business people, professionals and other individuals who compete with one another other for the "emerging power to shape politics" (Beck, 1994: 22). For Beck, sub-politics is borne from a lack of trust in traditional political institutions and is part of a necessary 'reinvention' of politics in an age of reflexive modernity. However, for others, such as Mouffe (2005: 48), dialogical modes of politics are built on the misguided premise that:

"Conflicts can be pacified thanks to the 'opening up' of a variety of public spheres where, through dialogue, people with very different interests will make decisions

\footnotetext{
${ }^{1}$ For example, in DCLG's (2012) 65-page NPPF document, mention is made of 'community' 49 times, while the word 'neighbourhood' is cited on 50 occasions.
} 
about the variety of issues that affect them and develop a relation of mutual tolerance allowing them to live together".

Others, such as Honig (1993: 2), observe the tendency to confine politics to "the juridical, administrative, or regulative tasks of stabilizing moral and political subjects, building consensus, maintaining agreements, or consolidating communities and identities" in which the task is to "get politics right, over, and done with". Such reflections highlight the potential subjugation of dissensus as part of a dialogic informed by claims to pragmatism, whereby 'getting things done' is the priority, and remains on the terms set by political or administrative elites and their networks (Crouch, 2004; Flyvbjerg, 1998; Callon et al, 2009).

Our interest is in bringing together these critical writings with those derived from a communicative planning perspective to (re)consider the opportunities available to those at the neighbourhood scale to challenge the prevailing socio-political order. This aim is underpinned by the belief that developing a detailed understanding of how dialogic politics operates at the local scale is necessary before moving to outright dismissal of such practices. This involves establishing a view of the (counter) tactics available to, and deployed by, different stakeholders, as well as the influences and variances that may be found within these. Expressed another way, our concern is to show how networks are assembled (and challenged) at the neighbourhood scale, to effect change in line with community demands. We do this through a focus on the practices of community-led planning (CLP), with its associated rhetoric that identifies partnership, cooperation and shared agenda-setting as progressive means to deliver community empowerment.

In exploring these issues, we highlight some of the local-level spaces of political engagement associated with neighbourhood-scale planning, and reflect on the potentials for transformative political action these may offer. These are questions that have, thus far, 
been neglected by critics of the post-political condition. Accounts have tended to privilege macro-scale analyses to the neglect of local-scale effects and interactions (see Paddison, 2010). We feel that a on local scale activity is important since this can indicate the potentials of localist structures and associated processes to enable actors to challenge and influence institutional activity beyond the neighbourhood or local scale.

We present a case study of an anti-noise campaign which gained momentum through a network of neighbourhoods formed through the CLP process. The network enabled residents from several villages to challenge and eventually shape national highways policy. We explore the points at which the campaign gained momentum, enabling communities to exert influence over existing policy frameworks. These points could be seen as critical junctures in the formulation of a sub-politics wherein individuals (and collectives thereof) act to shape agendas 'from below' by working through dialogical spheres located outside of formal and/or traditional political structures. Another reading, using the language of ANT, is that residents are contesting or destabilising the network translation. This is possible despite, and in some instances because of, what we have labelled political modulation, aimed variously at shaping, deflecting or dissuading challenges to the prevailing sociopolitical order.

While campaigners succeeded in making some changes to roadwork schedules reflecting their concerns about noise, the campaign also evidenced the ways in which community concerns were managed or modulated. The paper concludes that while there appears to be only limited scope for challenging the prevailing episteme within the planning policy context, there are instances where possibilities for resistance are created through (sub) local action. However, we observe that these are limited to those with the capacity and resources to use the system (selectively) to their advantage. If governments intend to facilitate community empowerment through mechanisms such as NP, then lessons drawn 
from such cases should inform the design and operation of dialogic spaces. Before turning to the case study, we outline the term modulation based on our reading of literature highlighting the limitations and possibilities of consensus-based approaches to planning.

\section{Political modulation and the management of difference}

The framing, (re)scaling and arbitration of claims and challenges to the established order are acknowledged as practices that have long been embedded in local politics and planning (see Albrechts, 2003; Allmendinger and Haughton, 2010; Elkin, 1974; Flyvbjerg, 1998; Paddison, 2010). Such observations resonate with the observations of Žižek (1999) who points to the emergence of a form of post-politics in which demands for change are isolated or compartmentalised to specific and localized complaints. Under these conditions, the ability to collectively challenge and change the existing hegemonic social order, and in so doing instigate politics 'proper', is effectively foreclosed (Oosterlynck and Swyngedouw, 2010; Swyngedouw, 2010).

We note that such practices are far from new, and that a number of devolved governance arrangements promising political empowerment at the local level have been identified as little more than façadist (for example: Bailey, 2003; Brownill, 2009; Geddes, 2006; Painter et al, 2011; Raco et al, 2006). Many policy experiments, such as neighbourhood working in urban regeneration (see Street, 2012) or community-led planning in rural areas (Parker and Murray, 2012), have been either short-lived or under-researched, or both. As a result there is little convincing evidence that demonstrates whether or not these structures have provided mechanisms through which localized agendas can shape more strategic priorities. Indeed, it may be that structures such as neighbourhood planning evidence both the opening up and closing down of possibilities wherein local agents can challenge and 
contest agendas and possibly shape outcomes that may otherwise be seen as determined or unchangeable.

In seeking to better understand these processes, we develop work (Gallent and Robinson, 2012; Parker, 2008; Parker and Murray, 2012) which indicates how specific political and resource conditions led to the promotion of a form of neighbourhood planning. This work shows that the scope and content of ideas and priorities generated by communities are circumscribed by policy mechanisms (cf. Callon, 1998; Dovey, 1999; Silver, 1997), while subsequent community-led attempts to challenge or reframe debates are also likely to be shaped and deflected by actors occupying authority positions, i.e. modulated.

Neighbourhood planning initiatives were initially designed with the aim of facilitating a greater understanding of local issues and to underpin a local representative democratic settlement. These 'roundtable' type solutions, as discussed further below, depend upon a crucial feature - the ability of lay people to engage with expert systems. Yet the long history of contestation, negotiation and bargaining within planning systems, often as part of routinized processes of consultation over formalized negotiation, has historically favoured the powerful. Such processes typically feature elements of what we term political modulation. The term 'modulation' is defined in two ways as: 1. exert a modifying or controlling influence on: i.e. the state attempts to modulate private business's cash flow; 2 . vary the strength, tone, or pitch of (one's voice): i.e. we all modulate our voice by hearing it.

With respect to the first standard definition, we understand modulation to be a process whereby control is exercised over local actors in and through the planning system and associated bureaucratic structures and processes. This occurs through a variety of tactics that sees community issues compartmentalized, separated and selectively downplayed or rescaled (see table 1). The second standard definition speaks to our concern to show how 
communities react to this modulation. In relation to the $\mathrm{M} 4$ noise issue we describe a range of counter-tactics used by residents, including amplifying demands through the use of social institutions (e.g. legislation) and collective action.

Thus modulation exchanges sit amongst and act to constitute part of the classic four stages or 'moments' of translation as described by Callon (1980; 1986), i.e. 'problematisation, interessement, enrolment and translation'. Moreover, our use of the term refines Callon's framework, particularly in respect of interaction within and across the interessement and enrolment stages of translation theory. This also reflects findings from earlier studies where networks were challenged by community interests (e.g. Parker and Wragg, 1999; Rutland and Aylett, 2008) and highlights both the messiness and dialogic nature of translation expressed in the intermediating notion of modulation and associated tactics employed.

The following table has been constructed from the literature, and explains the different facets of political modulation as may be seen in the planning process. The right-hand column indicates whether this element was evident in the case study.

Table 1. Features of dialogic exchanges - modulation

\begin{tabular}{|l|l|l|c|}
\hline $\begin{array}{l}\text { Form of } \\
\text { modulation }\end{array}$ & Description & Example & $\begin{array}{l}\text { Study } \\
\text { findings }\end{array}$ \\
\hline 1. Deflection & $\begin{array}{l}\text { Avoidance or part } \\
\text { acknowledgement of } \\
\text { issue or responsibility }\end{array}$ & $\begin{array}{l}\text { Failing to claim ownership of an issue or } \\
\text { problem, causing communities to look } \\
\text { elsewhere for the point of influence, perhaps } \\
\text { ultimately in vain }\end{array}$ & $\checkmark$ \\
\hline 2. Passing on & $\begin{array}{l}\text { Acting to shift } \\
\text { responsibility } \\
\text { elsewhere }- \text { could be } \\
\text { upscaling or }\end{array}$ & $\begin{array}{l}\text { Local authorities discouraging communities } \\
\text { from intervening in issues deemed 'too large' } \\
\text { for them, e.g. national infrastructure } \\
\text { provision, or stage A of the Community Led }\end{array}$ & $\checkmark$ \\
\hline
\end{tabular}




\begin{tabular}{|c|c|c|c|}
\hline & downscaling & Planning (CLP) process & \\
\hline 3. Delaying & $\begin{array}{l}\text { Slowing a process, } \\
\text { freezing out, boring } \\
\text { activists into giving up }\end{array}$ & $\begin{array}{l}\text { Drawing out or lengthening timeframes to } \\
\text { deter contributions or challenges from all but } \\
\text { the most persistent } \\
\begin{array}{l}\text { Delaying can also assist interests in } \\
\text { preparing arguments }\end{array}\end{array}$ & $\checkmark$ \\
\hline 4. Speeding up & $\begin{array}{l}\text { Expediting a formal } \\
\text { process, setting } \\
\text { deliberately short } \\
\text { timeframe for inputs }\end{array}$ & $\begin{array}{l}\text { Speeding up a decision-making process } \\
\text { reducing the opportunities for wider inputs } \\
\text { and/or engagement }\end{array}$ & $\checkmark$ \\
\hline 5. Rebuttal & $\begin{array}{l}\text { Explaining the issue } \\
\text { away }\end{array}$ & $\begin{array}{l}\text { Overwhelming or overloading communities } \\
\text { with complex information that they can't } \\
\text { understand }\end{array}$ & $\checkmark$ \\
\hline 6. Denial & $\begin{array}{l}\text { Refusing to } \\
\text { acknowledge an issue }\end{array}$ & $\begin{array}{l}\text { Argument that dissenters are 'making it up', } \\
\text { 'no proof' }\end{array}$ & \\
\hline $\begin{array}{l}\text { 7. 'Impossibility' } \\
\text { argument }\end{array}$ & $\begin{array}{l}\text { No viable alternative, } \\
\text { imperative to proceed, } \\
\text { Unaffordable, low } \\
\text { priority }\end{array}$ & Resource arguments, e.g. 'too costly' & $\checkmark$ \\
\hline $\begin{array}{l}\text { 8. Withholding } \\
\text { information }\end{array}$ & $\begin{array}{l}\text { Deliberate and } \\
\text { strategic release and } \\
\text { withholding of facts, } \\
\text { data, records or useful } \\
\text { names and contact } \\
\text { details }\end{array}$ & $\begin{array}{l}\text { Delaying or denying the existence of } \\
\text { information that campaigners need to } \\
\text { produce a 'logical' case or argument, e.g. } \\
\text { road use figures }\end{array}$ & $\checkmark$ \\
\hline $\begin{array}{l}\text { 9. Localising / } \\
\text { particularising }\end{array}$ & $\begin{array}{l}\text { Keeping the issue at } \\
\text { local or micro scale, } \\
\text { uniqueness stressed }\end{array}$ & $\begin{array}{l}\text { The tendency for 'experts' to manage and } \\
\text { reduce overall demands to singular or } \\
\text { particular complaints, marginalising them } \\
\text { and impeding collective action (see Žižek, } \\
\text { 1999) }\end{array}$ & $\checkmark$ \\
\hline $\begin{array}{l}\text { 10. Compartment- } \\
\text { alising }\end{array}$ & $\begin{array}{l}\text { Breaking the issue } \\
\text { apart and picking off } \\
\text { elements - keeping it } \\
\text { separate from other } \\
\text { issues }\end{array}$ & $\begin{array}{l}\text { Preventing communities from joining } \\
\text { together on campaign issues, e.g. by } \\
\text { removing or blocking channels of } \\
\text { communication }\end{array}$ & \\
\hline
\end{tabular}




\begin{tabular}{|c|l|l|l|}
\hline $\begin{array}{c}\text { 11. Closing down } \\
\text { / opening up }\end{array}$ & $\begin{array}{l}\text { Narrowing by framing } \\
\text { or opening up by } \\
\text { highlighting new } \\
\text { evidence or } \\
\text { unrecognised factors }\end{array}$ & $\begin{array}{l}\text { Can be used to both 'translate' or to } \\
\text { destabilise / reset terms of the } \\
\text { resolution/dispute. }\end{array}$ & $\checkmark$ \\
\hline
\end{tabular}

Given prevailing power asymmetries, some of which are likely to be compounded by policy arrangements such as NP contra to claims for empowerment (see Curry, 2012; Gallent and Robinson, 2012), typically local actors are on the receiving end of such tactics. This is not to deny the agency of non-experts, for example in deflecting modulation via the use of counter-tactics (as described in the following section). Indeed, we are of the view that local actors certainly could subject those in positions of authority to modulation. However, this is not what we observed in the M4 case study, nor what we would expect to see in the vast majority of cases.

\section{Fomentation and ferment? The role of neighbourhood planning in the M4 motorway anti-noise coalition}

A key question for us, which has been sharpened by recent debates about the extent to which planning can be considered post-political (see Bylund, 2012; Haughton et al, 2013), is the degree to which modulation prevents issues raised by communities from being recognized, magnified, collectivized or passed upwards and extrapolated. Initiatives or vehicles designed to promote a dialogic politics (and claim them as progressive) would need at least to allow for the reframing of issues and the challenging of hegemonic/dominant practices to take place. Yet governments seem to be largely unwilling to cede power or redistribute control, while wishing to appear to be doing so. It continues therefore to be an open question whether such opportunities can be effectively designed 
into vehicles such as NP, and, if so, whether they can provide the potential - intended or otherwise - to develop capacities to challenge the established order. In this section, we consider whether such spaces, in combination with other tools and resources, can play some part in achieving this.

Our concern to explore these spaces reflects the views of Paddison (2010: 20) who argues that politics may yet emerge in "interstices, in in-between spaces that have not yet come under the entrepreneurial gaze of the (local) state or in spaces where effective resistance can be mounted". We suggest that some of these gaps may develop within formal or semiformal planning structures and processes labelled as dialogic, rather than necessarily being dominated or obviated by them.

The literature on neighbourhood planning has tended to discuss efforts to engage communities in response to programmes or specific development proposals. As such, many accounts have focussed on practices of co-option, bargaining and the concessions that result from these processes (Bailey, 2003; Brownill, 2009; Cochrane, 2008). Other authors, such as those focussing on planning at the community scale, have looked at how planning is carried out in procedural terms or have considered the possibilities of bridging community plans horizontally and vertically (Gallent and Robinson, 2012; Parker, 2008; Parker and Murray, 2012). The wider public participation in planning literature has paid relatively little attention to the content and practices of collaborative spaces, structures and processes and the political impact of such spaces or instances. Careful examination of localist episodes in terms of the rules of engagement, framing of issues, and what is considered legitimate or not to be 'opened up' or rescaled is therefore needed.

The key questions become: when do dialogic politics (not) act to co-opt and / or marginalise of interests? Can opportunities for political debate be preserved within the 
local-level governance spaces that exist or may be on the agenda? Do the types of subpolitical forums envisaged by Beck (1994) warrant further critical attention, given that we know little about how are they are used or shaped by the parties involved (cf. Agger, 2012)? The development of understandings of episodic challenges in the forms of objection, protest or other constructive dissent, act to put into relief governmental claims about empowerment and localism, and may also present a counter-point to the largely pessimistic conclusions offered in the literature on the post-political condition.

The case study research involved in-depth interviews with key individuals and was enabled by earlier work that included a survey of all parishes in the district which who had engaged with community led planning (Parker 2008; Parker and Murray, 2012). The theme of longstanding conflict over M4 road noise issue emerged from that work as an issue that had been magnified as groups entered into horizontal networking during a CLP activity. The interviews used a semi-structured approach designed after a desk study of available literature on motorway protest and M4 policy and publications from official sources.

The interviewees were drawn from the initial survey sample and key contacts were involved. This enabled a snowball sampling technique to be employed whereby additional actors from intermediary organisations, including a representative from Berkshire Association of Local Councils, the Parish Council Clerk, two West Berkshire District Council employees, and a member of Community Council Berkshire were interviewed. The interviews lasted between one and two hours, and were conducted between April and June 2012.

The empirical discussion shows how a group of local people, based in a village in close proximity to the motorway, used a range of tactics and resources to pursue their agenda. This included careful and highly selective use of parts of the CLP 'toolkit' which provided a 
means of identifying and communicating a shared concern over motorway noise but also modulated campaigners' activities in a number of ways.

The West Berkshire district covers an area of approximately 270 sq miles. It is the 24th least deprived district in England (West Berkshire Council, 2011), with high levels of employment ${ }^{2}$ above-average house prices ${ }^{3}$ and a relatively well-educated population ${ }^{4}$. CLP was adopted and developed as a mechanism for engaging with constituent communities in the district, with political commitment and support at senior management level in the local authority (Parker and Murray, 2012). As a local authority representative confirmed: "here, from [the Chief Executive] down, we're fully committed to it [CLP]... it's almost like the blood running through your veins, it sounds a bit corny, but it's true".

CLP is intended to act as a way of gathering local views and attitudes, with a view to building a highly localized evidence base to inform agendas, ostensibly for co-governance (see Parker, 2008) with latter formulations including action plans. As table 2 shows, the CLP process typically involves a series of stages, with the action-planning element being the point at which the issues and actions identified as priorities by local communities are collated and filtered into a list or table (see also Gallent and Robinson, 2012).

\footnotetext{
2. $83 \%$ of the working age population in West Berkshire are economically active; this is higher than the rate for the South East region and nationally (West Berkshire Council, 2011).

3 . In July 2010 , the average house price in West Berkshire was $£ 225,739$ compared to $£ 166,694$ for England and Wales (West Berkshire Council, 2011).

4. $77.2 \%$ of West Berkshire's population is educated to Level 2 (five or more GCSE grades $A^{*}-C$ or vocational equivalent) while $33 \%$ is educated to Level 4 (includes first degree, 'other' degree and sub-degree higher education qualifications, HNC/HND and other HE diploma). This compares to $70.9 \%$ (L2) and $32 \%$

(L4) for England.
} 
Table 2. The ACRE 9-step Community-Led Planning process

\begin{tabular}{|c|c|}
\hline Stage & ACRE 9-step process \\
\hline Launch the plan & $\begin{array}{l}\text { 1. Getting started } \\
\text { 2. Establishing the steering group } \\
\text { 3. Taking stock and planning ahead }\end{array}$ \\
\hline Evidence local need and aspiration & 4. Understanding your community \\
\hline Agree and prioritise actions & $\begin{array}{l}\text { 5. Prioritising and planning action } \\
\text { 6. Drafting your plan } \\
\text { 7. Finalising your plan }\end{array}$ \\
\hline Deliver and monitor actions & $\begin{array}{l}\text { 8. Implementing and monitoring actions } \\
\text { 9. Reviewing your plan }\end{array}$ \\
\hline
\end{tabular}

(Source: ACRE, 2012)

It is during stage ' $A$ ' of the CLP process (5-7 as shown in the table above) that a local authority may typically exert a modifying or curbing influence over a local community's expressed needs and aspirations. Although some of the more determined neighbourhoods retained ambitious goals in their CLPs, in other cases it is evident that issues are being discounted or discouraged by community development workers and local authority officers (see Bishop, 2010). These actors are typically involved at other stages of the CLP process, for example, community development workers help to highlight to community members where their concerns had been raised elsewhere.

Notably, the action points that result from the CLP process tend to be relatively small-scale, measureable or achievable things, such as introducing traffic calming measures, or rebuilding a village hall. Indeed, the CLP process has tended to feature a number of key actors and 'stage-events' wherein modulation was either evident or clearly possible in the West Berkshire case (Table 1). The existence of such stages, and the opportunity to subvert or influence using associated tactics, are part of the routines, repertoires and choreography of political modulation. Our analysis of CLP in West Berkshire considers the 
points in the system at which such modulation has occurred, and shows how the challenging, and eventual reordering of, established institutional practices through the (selective) use of the CLP framework, was achieved.

\section{A context of planning controversy in West Berkshire}

A number of planning controversies have occupied local politics in West Berkshire in recent years. These include large-scale development proposals for housing, ongoing concerns about the operation of the Aldermaston nuclear research establishment and the location of a controversial waste incinerator. Road protest has been well established in the local consciousness too, and the area carries a legacy from the Newbury bypass protests of the mid-1990s (see Burningham, 1998; Rootes, 2009; Wall, 1999).

The M4 motorway was constructed in the early 1970s. It joins London in the east with south Wales in the west, and has been described as "the UK's main artery of prosperity" (Macleod et al, 2003: 1655; see figure 1). Our research indicates that, despite being a concern raised intermittently by residents living in the vicinity of the M4 for the last twenty years or so, the issue of road noise only began to gather momentum during the early 2000s. One interviewee explained that part of the problem for affected residents related to the surface of the motorway and the associated 'road rumble'. This became a central feature of the ensuing campaign:

"Unfortunately, what they laid down originally was a very large and substantial aggregate, which meant that it was very hard-wearing but it was damn noisy for everybody around and about. And of course at the time it was opened the traffic level was relatively low and consequently the noise wasn't a problem." (Resident interviewee) 
Figure 1. The M4 'corridor'

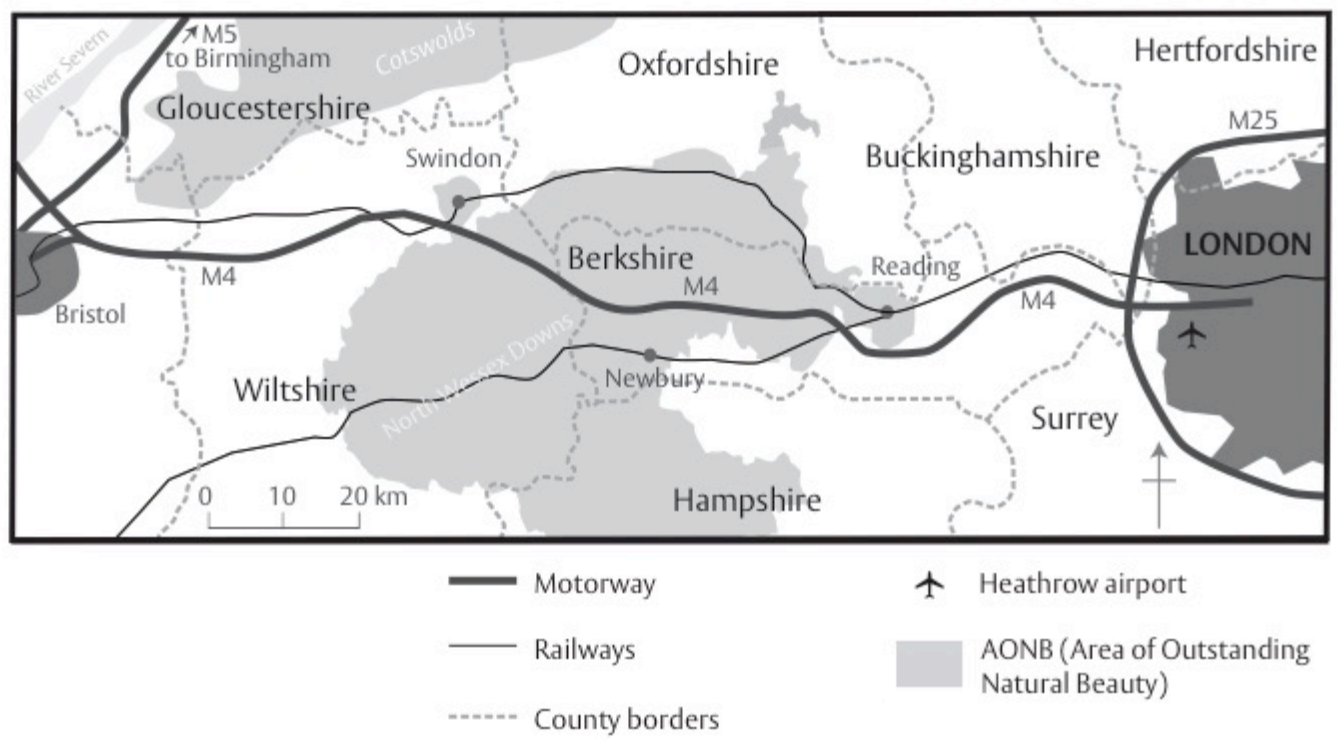

As road user numbers increased and the road surface deteriorated, the noise from the motorway became more acute and, by 2003 , as an interviewee involved in the campaign commented, "we were receiving complaints from people that, as a parish council, the noise was getting beyond a joke". The parish decided to use the CLP system as a vehicle for escalating their concerns about road noise. As one resident recalled:

"The parish council felt that it [CLP] would help...we were already struggling at that time to get any notice taken of us from the Highways Agency, and we thought if we had a parish plan [CLP] and that that reinforced the view that we already had, we might have a bit more power to our elbow." (Resident interviewee) 
The interviewee recalled how communication networks were forged through the CLP process:

"We realised that we were not the only ones in this section that had an issue with noise, and we asked other parish councils [if they had a problem]... and we got an overwhelming response..." (Resident interviewee)

Efforts to organise around this issue also helped to formalize residents' demands, following several years of complaints being made in an ad hoc manner. We observed that this tactic was used to overcome the technique of particularizing (see table 1), wherein the complaints of a group are consciously and deliberately kept 'local'. The village campaigners were aware their complaints could be perceived as marginal and thus actively sought to upscale their campaign via collectivising. This enabled them to resist the modulation of their concerns via a process of particularisation and use of the impossibility argument which they knew would reduce the power of their argument for road resurfacing:

"We have only maybe got, on their terms, probably half a dozen houses that are really affected by noise. It is... [a numbers issue]...it's got to be, and we appreciate that". (Resident interviewee)

While the campaign grew in size through coalition-building, facilitated by the CLP process, there remained a core group of activists who were the mobilising force of the campaign. This small group of between four and six individuals on the parish council, who called themselves the planning group, were supported in their efforts by the parish clerk. This core group were very aware of the benefits and pitfalls of CLP, and used different elements of the process selectively to aid the campaign. As an interviewee explained: "I tend to look at things warily...[l am] wary of leaping on bandwagons". The planning group was adamant 
they did things their way, rather than fully embracing the CLP model. As she remarked, "it's no good doing it like that in [our village]!"

The interviewee here is referring to a point within the CLP system wherein a form of modulation occurs. This particular stage-event is where communities are given assistance from local government officers to 'manage' their aspirations, and ensure that issues identified by them are 'achievable' priorities. As one West Berkshire officer explained:

"[It's about] realism and pragmatism...we do try and manage their expectations...we're trying to make sure that everything links back to the Sustainable Community Strategy's themes...so the Action Plans have to link to those themes...”. (Local Authority interviewee)

A community outreach worker described her role in the early stages of the CLP process in similar terms:

"My role has been a little bit to police it out in the communities and ensure best practice, but to do it in a way so that communities don't feel they're being told how to do it...helping them through the first sessions, that are often the hardest, but it gets easier, having the [ACRE] 9 steps [they] were strict for everyone to follow. Gently guiding people that's my role”. (Intermediary organisation interviewee)

Here the outreach work occupies a role akin to that of the technical 'expert' whose role is to broker consensual solutions (see table 1, Beck, 1994; Žižek, 1999). However, we observed that, despite the village group's reservations about the CLP process channelling them into particular ways of doing things, residents were able to selectively utilize parts of the CLP process to their advantage. This included facilitating access to West Berkshire's Highways 
Department, and more particularly, its officers' knowledge of road noise issues and mitigation techniques. As an interviewee explained, this was used to strengthen the case the campaign group made to the Highways Agency about the need for road resurfacing:

"[West Berkshire] Highways particularly was very useful to us when dealing with the Highways Agency...But we had an issue, we didn't understand why tree planting [one 'solution' offered by the HA] wouldn't work so we needed information from a sound engineer...we couldn't afford to go to a professional ...so we went to $[\mathrm{WBH}]$ and asked them for the information...[and also] where we might get more information that would be available to us free, and we got that information too". (Resident interviewee)

Restricted or delayed flows of information from the national Highways Agency (HA), which the campaigners circumvented using the tactics described above, was an issue that surfaced at several points over the duration of the campaign. As an interviewee reflected:

"We were asking for figures for traffic flow at different times of the day...About five years later we eventually got it...it was something they [the HA] didn't obviously want [us] to compare... which made it all the more important, urgent that we actually got hold of the figures". (Resident interviewee)

The village planning group were persistent, and responded by deploying counter-tactics, this time using European noise legislation to create a 'logical' argument around the need for resurfacing. This was then used to lobby the HA for further information on road user levels to further bolster the campaign's legitimacy:

"It's...a question of continually trying to push for information... [that] would give you an argument that...well now you've got to put down...the quiet surface because (a) you've 
got this directive from Europe, and (b) you can see the difference in the figures...the traffic flow, and just what a difference that makes". (Resident Interviewee)

The European Directive referred to here is '2002/49/E' on environmental noise ${ }^{5}$, something that the group were made aware of via their local MP after they lobbied him about the M4 road noise issue. The unearthing of the directive proved to be a key development in the campaign and helped 'open-up' the issue beyond the immediate locality. The noise mapping exercise was eventually carried in 2006, and highlighted where unacceptable levels of noise should be mitigated through measures such as screening or resurfacing. One interviewee explained the map's function:

"[It] shows you where they should be putting in noise mitigation measures. But that took quite a long time to [get produced], and that's only actually because the European Union had already started making noises about these certain directives about providing noise maps". (Resident interviewee)

The production of the noise maps, which validated the planning group's argument that its own village was subject to unacceptable noise levels, was a significant turning point in the campaign. Indeed, in 2008, the HA announced that an accelerated resurfacing schedule would be carried out, a conclusion that validated the community's concerns about noise caused by 'road rumble' and increased levels of road traffic. This represents some degree of success and a community 'win' - at least in the words of the Parish Plan:

"During the period of finalising the Parish Plan [CLP], the Highways Agency has resurfaced the westbound carriageway of the M4 with 'quieter tarmac' and advised that it will undertake some tree screening on the motorway verge. It has

\footnotetext{
${ }^{5}$ The Environmental Noise Directive 2002/49/EC. See: http://ec.europa.eu/environment/noise/directive.htm
} 
also indicated that the resurfacing of the eastbound carriageway is provisionally programmed....". (Source: Parish Plan for the village)

However, while the section of the M4 that housed those individuals who formed the driving force of the noise campaign was eventually resurfaced, other sections of road that were also highlighted as in need of mitigation measures through the mapping exercise were not. A member of the parish planning group felt this was because the champions needed to fight the cause over the long term (as they had) were not in place:

"But really on the other side [of the M4] there was nobody really willing to push it quite the same [even though] we would have supported [them]...you still need the same leadership in another area to carry it out for your own area, even if the other groups...are willing to support. And I have to say, I suppose after doing this for, what...maybe seven or eight years, to get anywhere, people do get tired. I think probably [Village $\mathrm{x}$ ] backed off and, although really they're quite ...badly affected by the [road] as well". (Resident interviewee)

As is so often the case in community-based campaigns, those engaged in the village - who remained engaged even when the issue dragged on - were those who had the time, resources, skills and something significant to lose, i.e. property value. A campaigner acknowledged that their group was made up of: "lots of ex-professional people...[We] were very fortunate in this respect". The road noise issue was predominantly a middle class concern. This resonates with the findings of Parker (2008), who argues that CLP can act to marginalise or 'double-exclude' some issues and groups for whom micro-level or localist efforts could potentially provide an opportunity for voice. 
The campaign's impact on West Berkshire's own Highways work programme was an unintended outcome. This provides an example where the opening-up of localised debate can effect change over established practices. As a representative from the authority explained, the CLP process has:

"[S]haped the [West Berkshire] Highways work programme, it's completely shaped it...because parish plans are saying we need this...and actually the Highways people are saying, we've got some priorities here shaped by the communities, and [as a result] they prioritise their highways programmes based on parish plans. [Without CLP] the Highways work programme that would've been delivered solely by officers, based on officers' views, has been reshaped by community thoughts, without a doubt".

The campaign group eventually succeeded in its goal to bring forward road resurfacing, and even gained (unintended) benefits such as the reshaping of WBH's work programme. However, this 'win' required a dogged and time-consuming lobby that was shaped and sustained by an articulate middle class group who had to deploy a range of tactics to resist, deflect and counter attempts to modulate their demands.

\section{Conclusion}

Our case study provides an insight into the ways that a self-aware and tenacious group has pursued a cause and made use of dialogic governance arrangements on their own terms. For Giddens (1994: 93), the decentralisation of political power is no less than a "condition of political effectiveness", dependent upon both a "requirement for bottom-up information flow as well as the recognition of autonomy". The M4 case shows how, having established some form of autonomy within the CLP process, residents were able to extract the 
information they needed to respond to and resist the modulation of their demands. The CLP mode provided a platform from which to orchestrate a challenge to the Highways Agency.

For those interested in the scope and formulations of what some have termed the "postpolitical' landscape of planning and policymaking, the lessons that can be drawn from the M4 road noise campaign focus on two competing processes. One coheres around attempts to forestall and foreclose through modulation. The second is the way in which the community group, in association with others - the network - used CLP, alongside their own reservoirs of power and influence, to make use of modulation techniques. Here Beck's (1997) observations about generative politics, through which (select) individuals are empowered with the tools to communicate their concerns through non-traditional or 'sub' political forums, appear apt. In the M4 noise case, the community group were adept at playing a game where they refused to be 'trapped' into one process or modality. Campaigners developed a choreography wherein no one party was ever in full control, using a combination or portfolio of tactics, combined with determined campaigning, to enact change from 'below'.

Critical writings about the post-political condition, as Dikeç (2005) points out, are premised upon very specific, sometimes divergent, understandings of politics, space and power. As such, this literature should be utilized consciously and carefully. We acknowledge the epistemological tensions associated with bringing together critical writings on the postpolitical condition, with planning literatures that have generally been much more positively disposed towards the progressive potential of dialogical modes of politics. With that said, we feel the concept of post-politics is powerful in bringing into focus the management or removal of dissensus in planning; something that the collaborative planning literature has paid comparatively little attention. 
There remains a lack of detailed scrutiny of particular cases, examples or instances of the ways in which groups engage in local place-making. For us, there is a need to reconsider the potentials for localised political action, based on a more thorough and somewhat wider examination of questions of process, history, scale, power and micro-level interactions. Our hope is that, by connecting oppositional theoretical viewpoints through empirical explanation, the debate around the political potential of the local scale is moved on. This is important as, while we sympathize with many of the criticisms made of dialogical politics, indications are that this style of governance will continue to find favour with politicians. In light of this, one of the challenges for proponents of dialogic planning mechanisms is to create resilient means to preserve spaces for transformative action. This would, at least potentially, allow for a more progressive dialogical politics to be fostered through community-scale action.

As we have argued in the paper, the promotion of dialogical modes of politics, can be seen as a way to engender collaborative action wherein: "[t]he questions of functional differentiation are replaced by the questions of functional coordination, cross-linking, harmonization, synthesis, and so on" (Beck, 1997: 27). However, the possibilities for transformative action within the discursive spaces of 'localist action' remain circumscribed and accessible only to those individuals with access to the necessary resources, infrastructures and repertoires. This complicates the picture that Beck (1997) paints. While the UK Coalition government purports to be creating new political spaces in developing Neighbourhood Planning (NP) (see DCLG, 2011b) the arenas within which local communities can act remain closely constrained. It would appear that it is only in very specific circumstances, and for the most determined and articulate communities, that NP (and similar initiatives) may provide a space for intervention in issues that communities deem important. For those aware of this potential, NP could be used in combination with a 
range of associated and complementary tools, tactics, resources and skills, however the problems associated with maintaining and utilising these spaces and orchestrating the required network relations are longstanding.

This brings the account onto some familiar ground wherein resources, knowledge, time, and gatekeepers' roles in the management/modulation of local/micro-politics is critical in shaping communities' ability to make effective or meaningful use of dialogic spaces. And thus in a general sense, such governance structures and outcomes appear inequitable, or at least unreliable sources of empowerment or progressive political action. The prerequisites for engendering change through localized activity around planning issues appear to be (unsurprisingly) access to the necessary skills and resource base for a sustained campaign. The 'buffering' role of intermediaries and institutions (e.g. quangos, community development workers, bureaucratic processes) which can assist and support campaigns, but may also be used to prevent issues from transcending from the local/specific to the strategic/shared, are all pertinent. In such circumstances the likelihood of dissensus being modulated, often as part of a pragmatic rationality expressed through justifications such as 'getting things done', is significant.

We contend that reflecting accurately on the wider condition of democratic politics is problematic. We have sought to identify those nodes or interfaces at which politics emerge, or, equally importantly, where attempts can falter. We acknowledge that there is little new about the emphasis on coordination and the 'management of difference', wherein dissensus is channelled into acceptable forms/channels, or else dismissed as unrepresentative. However, the example does show potential for local needs to be upscaled through processes of collectivization (see Rancière, 2010), e.g. neighbourhoods joining together in areas of shared concern, or through the innovative use of new media and access to data, and which the ability to communicate across boundaries assists. 
Initiatives or vehicles designed to promote a dialogic politics (and claim them as progressive) would need at least to allow for the reframing of issues and the challenging of hegemonic/dominant practices to take place. Yet governments seem unwilling to cede power or redistribute control, while wishing to appear to be doing so. It continues therefore to be an open question whether such opportunities can be effectively designed into vehicles such as NP, and, if so, whether they can provide the potential - intended or otherwise - to develop capacities to challenge the established order.

There needs to be a sharper focus on matters of process if we are to establish the possibilities (or lack of) for community actors to exercise influence over planning and policy decisions through localist governance frameworks. A more detailed investigation of cases and their outcomes needs to be undertaken with attention being paid to governmental efforts to modulate local political exchange. Analytical approaches derived from ANT perspectives could aid this agenda, acting to bring under scrutiny the fluid and contingent dynamics and formulations of dialogical political action. The portfolios of community groups need to be part of the examination to see where, how and if creative responses and tactics were orchestrated and applied.

Moreover, the factors that provoked, constrained or enabled these should be a research concern too. We argue that overall a more developed understanding of failures, by identifying the points of blockage, uncovering the mistranslation of demands, and showing the instances of bounded politics, boundary-setting and under-resourcing, that characterizes local and micro-scale politics, is still needed. This is imperative if we are to understand the 'hope' of (local) politics, or the spaces in which opportunities for localised action can be wrought within existing (and emergent) dialogical political frameworks. 


\section{References}

ACRE 2012, Community-led planning, located at: http://www.acre.org.uk/ourwork/community-led-planning (last accessed 28th July 2012)

Agger A, 2012, Towards tailor-made participation: how to involve different types of citizens in participatory governance, Town Planning Review 83(1) 29-45

Albrechts L, 2003, Reconstructing decision-making: planning versus politics, Planning Theory 2(3) 249-268

Allmendinger P, Haughton G, 2010, Spatial planning, devolution and new planning spaces, Environment and Planning 'C' 28(5) 803-818

Allmendinger P, Tewdwr-Jones M, 1998, Deconstructing Communicative Rationality: a critique of Habermasian collaborative planning, Environment \& Planning 'A' 30(11) $1975-1990$

Allmendinger P, Tewdwr-Jones, M, 2001, Planning Futures (Routledge, London)

Bailey N, (2003), Local strategic partnerships in England: the continuing search for collaborative advantage, leadership and strategy in urban governance, Planning Theory \& Practice 4(4) 443-457

Beck U, 1994, The reinvention of politics: towards a theory of reflexive modernization, in Reflexive Modernization Eds. U Beck, A Giddens, S Lash (Polity Press, Cambridge)

Beck U, 1997, The Reinvention of Politics: Rethinking Modernity in the Global Social Order (Polity Press, Cambridge)

Bishop J, 2010, From Parish Plans to Localism in England: Straight Track or Long and Winding Road? Planning Practice and Research 25(5) 611-624

Brenner N, Theodore N, 2002, Cities and the geographies of 'actually existing neoliberalism', Antipode 34 349-379

Brownill S, (2009), The Dynamics of Participation: Modes of Governance and Increasing Participation in Planning, Urban Policy and Research 27(4): 357-375

Burningham K, 1998, A noisy road or noisy resident? A demonstration of the utility of social constructionism for analysing environmental problems, The Sociological Review 46(3) 536-563

Bylund J, 2012, Post-political correctness? Planning Theory 11(3) 319-327

Callon M, 1980, 'Struggles and negotiations to define what is problematic and what is not', pp197-219 in Knorr, K, Krohn, R and Whitley, R. (eds.) The Social Process of Scientific Investigation, Vol. IV (Reidel, Dordrecht) 
Callon M, 1986, 'Some elements of a sociology of translation' pp196-223 in Law J. (ed.) Power, action, belief : a new sociology of knowledge. (Routledge, Kegan and Paul, London)

Callon M, 1998, An essay framing and overflowing, pp244-269 in Callon M, (ed.) The Laws of the Market. (Blackwell, Oxford)

Callon M, Lascoumes P, and Barthe Y, 2009, Acting in an uncertain world: an essay on technical democracy (MIT press, Boston).

Cameron D, 2010, "Our 'big society' plan”, 31 March, Conservative party, http://www.conservatives.com/News/Speeches/2010/03/David_Cameron_Our_Big_ Society_plan.aspx

Cochrane A, (2008) Understanding urban policy: A critical approach (Blackwell, Oxford)

Conservative Party, 2010, Open Source Planning, Discussion paper \#14 (The Conservatives, London)

Connelly S, 2006, Looking inside public involvement: how is it made so ineffective and can we change this? Community Development Journal 41(1) 13-24

Crouch C, 2004, Post Democracy (Polity Press, Cambridge)

Curry, N, 2012, Sustainable rural development in England: policy problems and equity consequences, Local Economy 27(2) 95-102

DCLG, 2011a, A Plain English Guide to the Localism Act Department for Communities and Local Government (The Stationery Office, London)

DCLG, 2011b, An Introduction to Neighbourhood Planning Department for Communities and Local Government (The Stationery Office, London)

DCLG, 2012, National Planning Policy Framework, 27 March, Department for Communities and Local Government (The Stationery Office, London)

Dikeç M, 2005, Space, politics, and the political, Environment and Planning D: Society and Space 23 171-188

Dovey K, 1999, Framing Places: Mediating Power in Built Form. (Routledge, London)

Elkin S, 1974, Politics and Land Use Planning (Cambridge University Press, Cambridge)

Elwood S, 2004, Partnerships and participation: reconfiguring urban governance in different state contexts, Urban Geographer 25(8) 755-770

Flyvbjerg B, 1998, Rationality and Power (University of Chicago Press, Chicago) 
Gallent N, Robinson S, 2012, Neighbourhood Planning: Communities, Networks and Governance (Policy Press, Bristol)

Geddes M, 2006, Partnership and the limits to local governance in England: institutionalist analysis and neoliberalism, International Journal of Urban and Regional Research 30(1) $76-97$

Giddens A, 1994, Beyond Left and Right: The Future of Radical Politics (Polity Press, Cambridge)

Haus M, Heinelt H, Stewart M, 2006, Urban Governance and Democracy (Routledge, London)

Haughton, G, Allmendinger, P, and Oosterlynck S, 2013, Spaces of neoliberal experimentation: soft spaces, postpolitics, and neoliberal governmentality, Environment and Planning 'A' 45217 - 234

Hoch C, 2006, What Can Rorty Teach an Old Pragmatist Doing Public Administration or Planning? Adminstration \& Society 38(3) 389-398

Innes J, Booher D, 2004, Reframing public participation: strategies for the $21^{\text {st }}$ century, Planning Theory and Practice 5 419-436

Macleod G, Raco M, Ward K, 2003, Negotiating the contemporary city, Urban Studies 40(9) 1655-1671

May T, 2008, The Political Thought of Jacques Rancière: Creating Equality (Edinburgh University Press, Edinburgh)

Metzger J, 2011, Commentary, Environment and Planning 'C' 29(2) 191-196

Mouffe C, 2005, On the Political (Routledge, London)

Oosterlynck S, Swyngedouw E, 2010, Noise reduction: the post-political quandary of night flights at Brussels airport, Environment and Planning 'A' 42(7) 1577-1594

Paddison R, 2010, Protest in the park: preliminary thoughts on the silencing of democratic protest in the neoliberal age, Variant 39/40 20-25

Painter J, Orton A, Macleod G, Dominelli L, Pande R, 2011, Connecting localism and community empowerment: research review and critical synthesis, report for the AHRC Connected Community Programme, Department of Geography, University of Durham

Parker G, 2012, 'Neighbourhood planning: Precursors, lessons and prospects', Paper to the Oxford Joint Planning Law conference $14^{\text {th }}-16^{\text {th }}$ September 2012. Journal of Planning and Environment Law 13 (2012 Supplement). Available at: http://www.quadrilect.co.uk/Gavin\%20Parker.pdf

Parker G, 2008, Parish and community-led planning, Town Planning Review 79(1) 61-85 
Parker G, Murray C, 2012, Beyond tokenism? Community-led planning and rational choices, Town Planning Review 83(1) 1-28

Parker G, Wragg A, 1999, Networks, Agency and (De)stabilization: The Issue of Navigation on the River Wye, UK, Journal of Environmental Planning and Management 42(4) $471-484$

Raco M, 2003, Assessing the discourses and practices of urban regeneration in a growing region, Geoforum 34 37-55

Raco M, Parker G, Doak A, 2006, Reshaping spaces of local governance? Community strategies and the modernisation of local government in England, Environment and Planning C: Government and Policy 24(4) 475-496

Rancière J, 2010, Dissensus: On Politics and Aesthetics (Continuum, New York)

Rootes C, 2009, Environmental movements, waste and waste infrastructure: an introduction, Environmental Politics 18(6) 817-834

Rutland T, and Aylett A, 2008, The work of policy: actor networks, governmentality and local action on climate change in Portland, Oregon, Environment and Planning D: Society and Space 26(4) 627-646

Sager T, 2009a, Planners' Role: Torn between Dialogical Ideals and Neo- liberal Realities, European Planning Studies 17(1) 65-84

Sager T, 2009b, Responsibilities of theorists: The case of communicative planning theory Progress in Planning 72(1) 1-51

Silver I, 1997, Constructing 'Social Change' through Philanthropy: boundary framing and the articulation of vocabularies of motives for social movement participation. Sociological Inquiry 67(4) 488-503.

Stirling A, 2008, 'Opening up' and 'closing down': power, participation, and pluralism in the social appraisal of technology, Science, Technology \& Human Values 33 262-294

Street E, 2012, (Re)shaping the South Bank: The (post) politics of sustainable placemaking. Unpublished PhD thesis, King's College, London

Swyngedouw E, 2005, Governance innovation and the citizen: the Janus face of governance-beyond-the-state, Urban Studies 42(11) 1991-2006

Swyngedouw, E, 2010, "Impossible sustainability and the post-political condition", pp 185205 in Making Strategies in Spatial Planning Knowledge and Values Eds. M Cerreta, G Concilio, V Monno (Springer, Dordrecht)

Tait M, 2002, Room for Manoeuvre? An Actor-network Study of Central-Local Relations in Development Plan Making, Planning theory and Practice, 3(1): pp 69-85

Wall D, 1999 Earth First! And the Anti-Roads Movement (Routledge, London) 
West Berkshire Council, 2011, West Berkshire District Profile 2011 (West Berkshire Council, Newbury)

Wilson N, 2005, The dark side of community development, Planning Theory and Practice 6: $519-526$

Žižek S, 1999 The Ticklish Subject (Verso, New York) 